\title{
EDITORIAL
}

\section{Fault zone hydrogeology: introduction to the special issue}

\section{MOTIVATION AND BACKGROUND}

The impacts of fault zones on fluid flow within the Earth's crust are notoriously difficult to characterize. Over the last several decades, structural geologists, petroleum engineers and hydrogeologists have investigated fault zones with the objective of understanding what factors and processes control fault zone hydraulic properties. Often these groups of researchers do not work together. One goal of this thematic issue is to highlight different investigation techniques (e.g. Bense et al. 2013) developed in one field that could be transferred into another discipline potentially shedding new light on long-standing research questions. This becomes especially significant when considering multiphase flow processes in faults such as in the context of $\mathrm{CO}_{2}$ storage or hydrocarbon production. A synergistic approach to fault zone hydrology research should narrow the gap in approaches and perceptions that exist across various research disciplines involved in the study of fault zone hydraulic properties. This special issue of Geofluids highlights ongoing work that jointly considers geological and hydrogeological aspects of fault zone properties.

\section{CONTENTS OF THE SPECIAL ISSUE}

Papers in the special issue are organized into the following themes: laboratory characterization of the impact of tectonic deformation on the evolution of hydraulic properties (Giwelli et al. 2016), field characterization of fault zone hydrogeology (Achtziger-Zupančič et al. 2016; Mundy et al. 2016), the impacts of faults on hydrothermal convection (Stober et al., 2016; Li et al. 2016) and relevance of fault zones for the leakage of $\mathrm{CO}_{2}$ from deep reservoirs (Bu et al. 2016; Raduha et al. 2016). One final paper attempts to raise awareness of trends and biases in how fault zone hydrogeological properties are characterized by different disciplines (Scibek et al. 2016).

\section{Laboratory studies of fault zone permeability evolution}

Laboratory studies of permeability alteration by Giwelli et al. (2016) demonstrate how the permeability in laminated carbonate rocks is altered by shearing. They found that during the first phase of deformation, permeability across the sheared plane was reduced. Permeability continued to decline with further shearing. Microstructural analyses using X-ray CT images revealed the development of a fault damage zone and fault core commonly seen in outcrop studies. This study provides interesting new insights into the scaling behaviour of fault zone deformation processes.

\section{Field characterization of fault zone properties from hydrogeological data}

Hydrogeological data provide an opportunity to test and validate models developed from laboratory and field examination of fault zone structure. Mundy et al. (2016) present field observations of fault zone structure of a mature thrust fault in carbonate rocks. Mundy et al. (2016) are able to colocate geological and hydrogeological observations, which is still a challenge in many fault zone hydrogeological studies. Achtziger-Zupančič et al. (2016) interpret a large data set of previously unpublished measurements of groundwater inflow rates into mines hosted in crystalline rocks. They used these inflow rates to estimate fault zone transmissivity (i.e. the product of fault hydraulic conductivity times fault zone thickness) for the permeable fracture zones that allow these inflow. Subsequently, they colocated these inflows with 3D geologic maps of fault zone architecture. Most of the inflows to the mine shafts occurred through the damage zones of faults. The rate of inflow was found to vary as function of strike orientation.

\section{Faults as conduits: hydrothermal circulation}

Faults can act as vertical conduits providing pathways for fluid transport through the Earth's crust (Sibson 1981). In many instances, hot spring discharge is focussed along deeply penetrating faults (Howald et al. 2015). The geochemistry, discharge rate and temperature of hot spring waters provide constraints on the circulation depth and fault zone properties.

The Da Qaidam hot springs in China were analysed by Stober et al., (2016). The authors were able to constrain the hydrogeological characteristics of this geothermal system using geochemical and temperature data. The reconstruction by Stober et al. can be described as an inverse modelling exercise. In contrast, numerical models of coupled fluid flow and heat transport by $\mathrm{Li}$ et al. (2016) illustrate the ability of forward models to assess the impact of hydraulic and thermal parameters on hydrothermal circulation patterns in the crust in which permeable fault zones play a crucial role in for formation of metal ore deposits. 
Li et al. (2016) used FLAC3D, a widely used hydrogeomechanics code, to evaluate the occurrence of uranium deposits beneath the Athabasca Basin, Canada. They infer that the location and thermal conductivity of fault zones near the interface between the crystalline basement and Palaeozoic sediments played an important role in the development of economic, unconformity-related uranium mineralization.

\section{Faults as seal and/or conduits: reservoir studies}

The potential for faults to provide potential leak points for sequestered $\mathrm{CO}_{2}$ in deep reservoirs has been a long-standing concern in the carbon capture and storage community (e.g. Rudqvist et al. 2006). Two studies in this special issue ( $\mathrm{Bu}$ et al. 2016; Raduha et al. 2016) consider this aspect of fault zones through a combination of field data collection and numerical modelling of multiphase flow.

Raduha et al. (2016) evaluated the potential impact of mesoscale fault systems through caprocks on possible $\mathrm{CO}_{2}$ leakage from reservoirs. They constructed fault zone hydrogeological models based upon detailed outcrop measurements of permeability of various fault zone elements (i.e. deformation bands and fractures) from exposed fault zones in the Entrada Sandstone, Utah. Their fault zone hydrogeological framework model was incorporated into a multiphase $\left(\mathrm{CO}_{2}-\mathrm{H}_{2} \mathrm{O}\right)$ reservoir model in order to evaluate the impact of faults on seal bypass. The authors found that the extent of fault penetration through the cap rock played an important role in determining whether or not a fault can permit leakage of supercritical $\mathrm{CO}_{2}$. These authors also argued that storage of $\mathrm{CO}_{2}$ within the caprock via fracture transport represents a potential storage reservoir for carbon.

$\mathrm{Bu}$ et al. (2016) used geological data from the Ordos $\mathrm{CO}_{2}$ geological storage demonstration project site in north-western China, where $\mathrm{CO}_{2}$ is injected into a sandstone-mudstone sequence. These authors used geological data from well logs of the stratigraphy of the reservoir because no direct observations of fault zones were available. They used idealized hydrologic model simulations to illustrate how a conductive fault in a reservoir at some distance from a $\mathrm{CO}_{2}$ injection well would start to act as a leak point between reservoir and adjacent mudstone intervals. These authors argued that migration of $\mathrm{CO}_{2}$ away from the injection well further into the host rock is enhanced by the presence of faults.

\section{Detecting generic trends and patterns in fault zone hydrogeology}

The reported hydrologic behaviour of fault zones can vary depending on the geologic setting and conditions as well as the underlying goals of the research community undertaking the investigation (Bense et al. 2013). Scibek et al. (2016) attempted to identify whether observational bias exists, by bringing together as many data sets as possible from various published sources ranging from hydrogeological investigations, mining studies, structural geology and hydrocarbon reservoir research. These authors then set out to establish whether any particular approach, and/or background of the research team, led to a bias in how fault zones are viewed (i.e. as conduits, barriers or conduit-barrier systems). The authors conclude that the observation method, geoscience discipline and lithology are three important factors in how a fault zone is characterized and that observational bias does exist.

\section{Gaps in knowledge}

Despite the important contributions of this thematic issue in advancing our understanding of fault zones, significant gaps exist in our understanding of multiphase fluid properties and transport processes of faults. Of particular interest and areas with significant gaps are (i) the relative permeability behaviour of fractures and faults to brine, $\mathrm{CO}_{2}$ and hydrocarbon fluids; (ii) the impacts on flow rates of counter-current and Poiseuille flow in large fracture apertures where capillarity does not dominate flow; (iii) effective means for characterizing transfer functions between fractures and matrixes for multiphase fluids; and (iv) the coupling of hydro-geochemical-geomechanical processes and it impact on the flow properties of fault zones. Significant advances in experimental techniques including $\mu$-CT imaging techniques and triaxial flow cells are beginning to shed light on some of the fluid dynamics at small scales. For flow at the meso- and macroscale, integrated laboratoryand field-scale observations, together with advanced numerical modelling techniques, are required to understand and predict the flow behaviour. Macroscale flow in faults is, however, crucially affected by within- and alongfault heterogeneity, so multiscale approaches are crucial. A lack of well-characterized field-scale experiments on flow and transport processes across and within fault zones limits the advancement of this discipline. Further, synergies between researchers working on advanced numerical modelling codes, field-scale hydrogeological observations and experimentation are required to fundamentally advance the science of fault zone hydrogeology.

\section{CONCLUDING REMARKS}

The papers in this special issue provide a snapshot of current approaches, both novel and based upon established techniques, to elucidate fault zone hydrogeological behaviour from field observations. These papers show the broad context to which fault zone hydrogeology is relevant. They show the range of techniques and expertise required to address these 
fundamental issues and the advancements that are being made through an integrated and synergistic approach.

Understanding the flow properties of faults is critical to issues spanning many disciplines of the geological sciences and subjects including geoenergy extraction, waste and energy storage, groundwater and the environment. A lack of fundamental understanding of fault-related flow properties and processes undermines issues ranging from risk assessment of $\mathrm{CO}_{2}$ storage projects to the effective management of hydrocarbon, geothermal and groundwater resources. Continued research ranging from experimentation, hydrogeological field observations and advanced modelling techniques are required to address this critical area.

Victor Franciscus Bense ${ }^{1}$, Zoe Kal Shipton ${ }^{2}$, Yannick Kremer ${ }^{2}$ and NiKo KAMPMAN ${ }^{3}$

${ }^{1}$ Wageningen University and Research, Wageningen, Netherlands; ${ }^{2}$ University of Strathclyde, Glasgow, United Kingdom; ${ }^{3}$ Shell Global Solutions International, Rijswijk, Netherlands

\section{REFERENCES}

Achtziger-Zupančič P, Loew S, Hiller A, Mariethoz G (2016) 3D fluid flow in fault zones of crystalline basement rocks (PoehlaTellerhaeuser Ore Field, Ore Mountains, Germany). Geofluids, 16, 688-710.

Bense VF, Gleeson T, Bour O, Loveless S, Scibek J (2013) Fault zone hydrogeology. Earth Science Reviews, 127, 171-92.

Bu F, Xu T, Wang F, Yang Z, Tian H (2016) Influence of highly permeable faults within a low-porosity and low-permeability reservoir on migration and storage of injected $\mathrm{CO}_{2}$. Geofluids, 16, 769-781.

Giwelli A, Delle Piane C, Esteban L, Clennell MB, Dautriat J, Raimon J, Kager S, Kiewiet L (2016) Laboratory observations of fault transmissibility alteration in carbonate rock during direct shearing. Geofluids, 16, 658-672.

Howald T, Person M, Campbell A, Lueth V, Hofstra A, Sweetkind D, Gable CW, Banerjee A, Luijendijk E, Crossey L, Karlstrom K, Kelley S, Phillips F (2015) Evidence for long-time scale ( $>10^{3}$ years) changes in hydrothermal activity induced by seismic events. Geofluids, 15, 252-268.

Mundy EM, Dascher-Cousineau K, Gleeson T, Rowe CD, Allen DM (2016) Complexity of hydrogeologic regime around an ancient low-angle thrust fault revealed by multidisciplinary field study. Geofluids, 16, 673-687.

Raduha S, Butler D, Mozley PS, Person M, Evans J, Heath JE, Dewers TA, Stauffer PH, Gable CW, Kelkar S (2016) Potential seal bypass and caprock storage produced by deformation-bandto-opening-mode-fracture transition at the reservoir/caprock interface. Geofluids, 16, 752-768.

Rudqvist J, Birkholzer J, Tsang CF (2006) Modelling hydrological and geochemical processes related to $\mathrm{CO}_{2}$ injection in a faulted multilayer system. In: Proceedings of the GHGT8 ConferenceTrondheim (Norway), pp. 18-22.

Scibek J, Gleeson T, McKenzie JM (2016) The biases and trends in fault zone hydrogeology conceptual models: global compilation and categorical data analysis. Geofluids, 16, 782-798.

Sibson RH (1981) Fluid flow accompanying faulting: field evidence and models. In: Earthquake Prediction-An International Review: American Geophysical Union Monograph, Maurice Ewing Series, Vol. 3 (eds Simpson DW, Richards PG), pp. 593-603. American Geophysical Union, Washington, DC. 


\section{GEOFLUIDS}

Volume 16, Number 4, November 2016

ISSN 1468-8115

\section{CONTENTS}

655 EDITORIAL: Fault zone hydrogeology: introduction to the special issue V.F. Bense, Z.K. Shipton, Y. Kremer and N. Kampman

658 Laboratory observations of fault transmissibility alteration in carbonate rock during direct shearing

A. Giwelli, C. Delle Piane, L. Esteban, M.B. Clennell, J. Dautriat, J. Raimon, S. Kager and

L. Kiewiet

673 Complexity of hydrogeologic regime around an ancient low-angle thrust fault revealed by multidisciplinary field study

E.M. Mundy, K. Dascher-Cousineau, T. Gleeson, C.D. Rowe and D.M. Allen

688 3D fluid flow in fault zones of crystalline basement rocks (Poehla-Tellerhaeuser Ore Field, Ore Mountains, Germany)

P. Achtziger-Zupančič, S. Loew, A. Hiller and G. Mariethoz

711 Deep hydrothermal fluid-rock interaction: the thermal springs of Da Qaidam, China I. Stober, J. Zhong, L. Zhang and K. Bucher

729 The effects of basement faults on thermal convection and implications for the formation of unconformity-related uranium deposits in the Athabasca Basin, Canada

Z. Li, G. Chi and K.M. Bethune

752 Potential seal bypass and caprock storage produced by deformation-band-toopening-mode-fracture transition at the reservoir/caprock interface

S. Raduha, D. Butler, P.S. Mozley, M. Person, J. Evans, J.E. Heath, T.A. Dewers,

P.H. Stauffer, C.W. Gable and S. Kelkar

769 Influence of highly permeable faults within a low-porosity and low-permeability reservoir on migration and storage of injected $\mathrm{CO}_{2}$

F. Bu, T. Xu, F. Wang, Z. Yang and H. Tian

782 The biases and trends in fault zone hydrogeology conceptual models: global compilation and categorical data analysis

J. Scibek, T. Gleeson and J.M. McKenzie 